\title{
Effects of Biopriming on Germination Characteristics of PMK (R) 4 under Salinity Conditions
}

\author{
N. Nithya ${ }^{1 *}$, R. Geetha ${ }^{1}$, K. Sivasubramaniam ${ }^{1}$, N.O. Gopal ${ }^{2}$ and C. Vanniarajan ${ }^{3}$ \\ ${ }^{1}$ Department of Seed Science and Technology, ${ }^{2}$ Department of Microbiology, ${ }^{3}$ Department of \\ Plant Breeding and Genetics, Agricultural Collage and Research Institute, Madurai, \\ Tamil Nadu Agricultural University, Tamil Nadu, India \\ *Corresponding author
}

\section{A B S T R A C T}

\begin{tabular}{|l|}
\hline Ke y w o r d s \\
Biopriming, \\
Germination, \\
Salinity. \\
\hline Article Info \\
\hline $\begin{array}{l}\text { Accepted: } \\
10 \text { October } 2017 \\
\text { Available Online: } \\
10 \text { December } 2017\end{array}$ \\
\hline
\end{tabular}

Study was conducted to determine the effect of seed bio-priming on germination and vigour of rice under salinity stress condition. Seeds of rice var. PMK (R) 4 were primed with water, liquid formulation of azospirillum, phosphobacteria, silicate soluble bacteria and their combinations at $20 \%$ concentration for $18 \mathrm{~h}$. at $25^{\circ} \mathrm{C}$ and evaluated under salt stress conditions created by $0.25,0.50,0.75$ and $1.0 \% \mathrm{NaCl}$ solutions for its germination, vigour index, seedling length, dry matter production, total phenol, chlorophyll and malondialdehyde content were studied. The untreated dry seeds served as control. Results revealed that seeds bio-primed with combinations of azospirillum + phosphobacteria @ $20 \%$ solution for $18 \mathrm{~h}$ performed better in germination and vigour and also maximum phenol content and lower MDA content at $8 \mathrm{dSm}^{-1} \mathrm{NaCl}$ concentration. The next best bioinoculant was $20 \%$ of azospirillum alone. Hence, suggested azospirillum + phosphobacteria @ 20\% solution as a best seed enhancement technique for improving seed germination of rice under salinity stress condition.

\section{Introduction}

Poor soil health and polluted environment is the major cause for lower productivity in Indian Agriculture. Soil Salinity is one of the important factor which limits plant growth at all developmental stages by creating an osmotic pressure that prevent germination of seeds and decrease water uptake of plant roots, due to ionic toxicity of $\mathrm{Na}+$ and $\mathrm{Cl}^{-}$ (Almansouri et al., 2001) which ultimately leads to lower productivity (Epstein et al., 1980: Lutts et al., 2004; Yagmur and Kaydan, 2008). Though high quality seeds are used for sowing in the field, it undergoes many stresses during the emergence and establishment leading to poor survival and reduced plant stands on the main field.

Salinity, as an abiotic hazard, induces numerous disorders in seeds and propagules during germination. Salinity either completely inhibits germination at higher levels or induces a state of dormancy at lower levels (Khan and Ungar, 1997).

Salinity affects germination by facilitating the intake of toxic ions, which can cause change of certain enzymatic or hormonal activities of the seed. Salinity has been reported to cause 
significant reductions in the rate and final percentage of germination and emergence of radish, which in turn may lead to uneven stand establishment and ultimately reduced crop yields.

Seed priming a pre sowing seed enhancement technique, enhances the speed, vigour and uniformity of seedling formation (Demir and Van De Venter, 1999). Seed priming with bio-agents not only improves the germination but also increases stress tolerance during early seedling growth (Krishna et al., 2008; Fallahi et al., 2011). In order to overcome the salt stress during seed germination, several authors have recommended different seed priming techniques such as hydropriming, halopriming, osmopriming and solid matric priming.

Bio priming is also a sustainable tool to improve the stress tolerance capacity of seeds during early seedling growth (Fallahi et al., 2011). Hence, this present study was formulated to investigate the effect of biopriming of rice seeds under salinity conditions upon their germination and vigour during the early growth stages.

\section{Materials and Methods}

Seeds of rice var. $\operatorname{PMK}(\mathrm{R}) 4$ with an initial germination of $90 \%$ and $10.2 \%$ moisture were used for these studies. Experiments were carried out in the Department of Seed Science and Technology, Agricultural College and Research Institute, Madurai (TNAU). Total nine treatments were followed with three replications, along with control.

The nine treatments follows as untreated seeds as a control $\left(\mathrm{T}_{0}\right)$, Seeds soaked in water (Hydro priming) $\left(\mathrm{T}_{1}\right)$; and seeds treated with $20 \%$ solutions of azospirillum $\left(\mathrm{T}_{2}\right)$; phosphobacteria $\left(\mathrm{T}_{3}\right)$; silicate soluble bacteria $\left(\mathrm{T}_{4}\right)$; azospirillum + phosphobacteria $\left(\mathrm{T}_{5}\right)$; azospirillum + silicate soluble bacteria $\left(\mathrm{T}_{6}\right)$; phosphobacteria + silicate soluble bacteria $\left(\mathrm{T}_{7}\right)$ and azospirillum + phosphobacteria + silicate soluble bacteria $\left(\mathrm{T}_{8}\right)$ with a soaking duration of $18 \mathrm{~h}$ at $25^{\circ} \mathrm{C}$ respectively for all the bio-inoculants. Then the bio-inoculants treated seeds were dried to its original moisture content and evaluated for its germination potential under induced salinity stress conditions created by using $\mathrm{NaCl}$ at different concentration of $0.25 \%, 0.50 \%$, $0.75 \%$ and $1.0 \%$ expressing the electrical conductivity (EC) values of $2,4,6$ and 8 $\mathrm{dSm}^{-1}$ respectively. The germination media was moistened with $\mathrm{NaCl}$ solution for the entire period of germination as per the treatment and germination test was conducted.

Seeds were considered as germinated when radicals were $2 \mathrm{~mm}$ long. Speed of germination was recorded every $24 \mathrm{~h}$ for 14 days (Maguire, 1962) and percentage of germination was calculated (ISTA, 2009). Root length, shoot length were also measured at the end of $14^{\text {th }}$ days. Vigour index was calculated using the formula of Abdul-Baki and Anderson (1973).The end of 14 days of germination, total chlorophyll content (Yoshida et al., 1971) and total phenol content (Thimmaiah, 1999), Malondialdehyde (MDA) content (Heath and Packer, 1968) were also estimated using the seedlings raised under salt stress conditions against hydropriming.

For the comparison amongst treatments, salt tolerance index was calculated where, a salt sensitive treatment was chosen as susceptible standard and the performance of other treatments were compared (Zeng et al., 2003).

The untreated seeds served as susceptible standard as it had highest mean for MDA content and lower mean for other characters. 
Salt tolerance index $=$

Mean of a treatment for a trait over salt stress treatments

Mean of susceptible standard for the trait over salt stress treatments

The data obtained from different experiments were analyzed by the ' $F$ ' test of significance (Panse and Sukhatme, 1985). Wherever necessary, the per cent values were transformed to angular (arc-sine) values before analysis. The critical differences (CD) were calculated at 5 per cent probability level.

\section{Results and Discussion}

Seed bio-priming with $20 \%$ solutions of all the organisms had a significant impact on speed of germination and germination percentage under saline conditions compare to control. Under zero level of salinity, the highest speed of germination was register with seeds bio-primed with azospirillum + phosphobacteria $\left(\mathrm{T}_{5}\right)$ (4.6) compared to control (3.6) and all other treatments (Figure $1)$.

Bio-priming might have improved the stress tolerance capacity during early seedling growth in which crop (Fallahi et al., 2011).

The maximum germination (96\%) was achieved in rice seeds bio-primed with azospirillum and phosphobacteria $\left(\mathrm{T}_{5}\right)$ when compare with normal conditions $(0 \%)$.

The same trend was observed in $T_{5}$ (azospirillum + phosphobacteria) under saline conditions also, it registered maximum germination $(93 \%)$ with salt tolerance index of 0.61 than all other bio-priming treatments. Minimum germination $(84 \%)$ was in unprimed seeds (control) at all stress levels with salt tolerance index of 1.00 in each (Figure 2).
Poor germination under salt stress conditions was due to an osmotic effect and ion toxicity. Salt stress causes reactive oxygen species stress, leading to gradual peroxidation of lipid and antioxidant enzyme inactivation and finally reduces germination and plant growth (Song et al., 2008; Zheng et al., 2009). In the present study, seedling length was also much affected and it decreased as salt stress increased. The shoot and root length reduced to almost $25 \%$ from the normal growth of 8.6 $\mathrm{cm}$ and $15.0 \mathrm{~cm}, 6.0 \mathrm{~cm}$ and $13.4 \mathrm{~cm}$, respectively at the stress level of $1 \%$ in untreated plants (control).

However, it could be noted that seedlings obtained from $\mathrm{T}_{5}$ (azospirillum + phosphobacteria) had significantly higher shoot and root length than control $(8.7 \mathrm{~cm}$ and $15.0 \mathrm{~cm}$, respectively at $1 \% \mathrm{NaCl})$. Seed biopriming with azospirillum has a positive effect on the production of plant growth hormones increased the number of root hairs, seedling length and dry matter concentration of wheat, sesame, canola and bean (Mirshekari and Baser, 2010).

In the present study also next to treatment $\left(\mathrm{T}_{5}\right.$-azospirillum + phosphobacteria) azospirillum treated seeds $\left(\mathrm{T}_{2}\right)$ expressed its vigour in term of root and shoot length $(13.8 \mathrm{~cm}$ and $7.5 \mathrm{~cm})$ under stress conditions (Table 1).

When salinity was increased to $1 \%$ level, fresh and dry weight of seedlings decreased irrespective of the treatments. It is probably due to decrease in remobilization of reservoirs from cotyledons to embryo axis (Akita and Cabuslay, 1990). Drastic reduction in plumule length of wheat, barley, pea and cabbage seeds when salinity stress was increased (Mer et al., 2000). They pointed out that decreasing growth was because of reduced water absorption by radicle, and subsequently by accumulation of soluble salts in cells and water potential of root cells decreases. 
Table.1 Effect of seed biopriming on root length, shoot length and dry matter production in rice var. PMK 4-under salt stress condition

\begin{tabular}{|c|c|c|c|c|c|c|c|c|c|c|c|c|c|c|c|c|c|c|}
\hline \multirow{2}{*}{$\begin{array}{c}\text { Treatments/ } \\
\text { Different } \\
\text { concentration } \\
\text { of } \mathrm{NaCl}(\%)\end{array}$} & \multicolumn{6}{|c|}{ Root Length (cm) } & \multicolumn{6}{|c|}{ Shoot Length $(\mathrm{cm})$} & \multicolumn{6}{|c|}{ Dry matter production (g/10 seedlings) } \\
\hline & $\mathbf{0}$ & $0.25 \%$ & $0.50 \%$ & $0.75 \%$ & $1 \%$ & mean & $\mathbf{0}$ & $0.25 \%$ & $0.50 \%$ & $0.75 \%$ & $1 \%$ & mean & $\mathbf{0}$ & $0.25 \%$ & $\mathbf{0 . 5 0 \%}$ & $0.75 \%$ & $1 \%$ & mean \\
\hline T0 & 15 & 14.8 & 14.5 & 13.4 & 10 & 13.5 & 8.6 & 8.3 & 7.7 & 7.1 & 6 & 7.5 & 1.000 & 0.099 & 0.093 & 0.086 & 0.082 & 0.272 \\
\hline $\mathrm{T} 1$ & 17.2 & 16.2 & 16 & 15 & 11.3 & 15.1 & 10 & 8.6 & 7.8 & 7.4 & 6.4 & 8.0 & 1.004 & 1.002 & 1.000 & 0.096 & 0.091 & 0.639 \\
\hline $\mathrm{T} 2$ & 19.5 & 18 & 17.3 & 16.8 & 13.8 & 17.1 & 11 & 10 & 9 & 8.4 & 7.5 & 9.0 & 1.110 & 1.108 & 1.005 & 1.000 & 0.096 & 0.864 \\
\hline $\mathrm{T} 3$ & 17.6 & 16.9 & 16.3 & 15.5 & 13.5 & 16.0 & 10.2 & 9.8 & 8.5 & 7.8 & 6.6 & 8.6 & 1.100 & 1.006 & 1.003 & 0.097 & 0.093 & 0.660 \\
\hline $\mathrm{T} 4$ & 17 & 16 & 15.8 & 14.8 & 12 & 15.1 & 9.8 & 8.3 & 8 & 7.3 & 6.3 & 7.9 & 1.000 & 1.000 & 0.098 & 0.094 & 0.091 & 0.457 \\
\hline T5 & 20 & 19.2 & 18.6 & 18.2 & 15 & 18.2 & 11.8 & 11 & 10.3 & 9.4 & 8.7 & 10.2 & 1.120 & 1.116 & 1.111 & 1.107 & 1.100 & 1.111 \\
\hline T6 & 17.7 & 16.8 & 16.3 & 15.5 & 12 & 15.7 & 10.4 & 9 & 8.4 & 7.6 & 7 & 8.5 & 1.007 & 1.004 & 1.000 & 0.095 & 0.094 & 0.640 \\
\hline $\mathrm{T} 7$ & 15.6 & 15.4 & 14.6 & 14 & 11.3 & 14.2 & 8.8 & 8.2 & 8 & 7.2 & 6.1 & 7.7 & 1.002 & 0.099 & 0.094 & 0.09 & 0.089 & 0.275 \\
\hline T8 & 18.6 & 17.8 & 17 & 16 & 13 & 16.5 & 10.7 & 9.6 & 8.8 & 8.1 & 6.8 & 8.9 & 1.008 & 1.006 & 1.001 & 0.096 & 0.092 & 0.641 \\
\hline Mean & 17.6 & 16.8 & 16.3 & 15.5 & 12.4 & 15.7 & 10.1 & 9.2 & 8.5 & 7.8 & 6.8 & 8.5 & 1.039 & $\mathbf{0 . 8 2 7}$ & 0.712 & 0.307 & 0.203 & 0.617 \\
\hline \multirow{2}{*}{$\operatorname{SE}(d)$} & \multicolumn{2}{|c|}{$\mathbf{T}$} & \multicolumn{2}{|c|}{$\mathbf{C}$} & \multicolumn{2}{|c|}{ TXC } & \multicolumn{2}{|r|}{$\mathbf{T}$} & \multicolumn{2}{|c|}{$\mathbf{C}$} & \multicolumn{2}{|c|}{ TXC } & \multicolumn{2}{|c|}{ T } & \multicolumn{2}{|c|}{$\mathbf{C}$} & \multicolumn{2}{|c|}{ TXC } \\
\hline & \multicolumn{2}{|c|}{0.187} & \multicolumn{2}{|c|}{0.139} & \multicolumn{2}{|c|}{0.418} & \multicolumn{2}{|c|}{0.081} & \multicolumn{2}{|c|}{0.060} & \multicolumn{2}{|c|}{0.181} & \multicolumn{2}{|c|}{0.009} & \multicolumn{2}{|c|}{0.007} & \multicolumn{2}{|c|}{0.021} \\
\hline CD $(0.05 \%)$ & \multicolumn{2}{|c|}{$0.370 * *$} & \multicolumn{2}{|c|}{$0.275 * *$} & \multicolumn{2}{|c|}{$0.827 * *$} & \multicolumn{2}{|c|}{$0.160 * *$} & \multicolumn{2}{|c|}{ 0.119** } & \multicolumn{2}{|c|}{$0.359 * *$} & \multicolumn{2}{|c|}{ 0.019** } & \multicolumn{2}{|c|}{$0.014 * *$} & \multicolumn{2}{|c|}{$0.043 * *$} \\
\hline
\end{tabular}

Table.2 Effect of seed biopriming on total chlorophyll, total phenol content and MDA in rice var. PMK 4 - NaCl salt stress condition

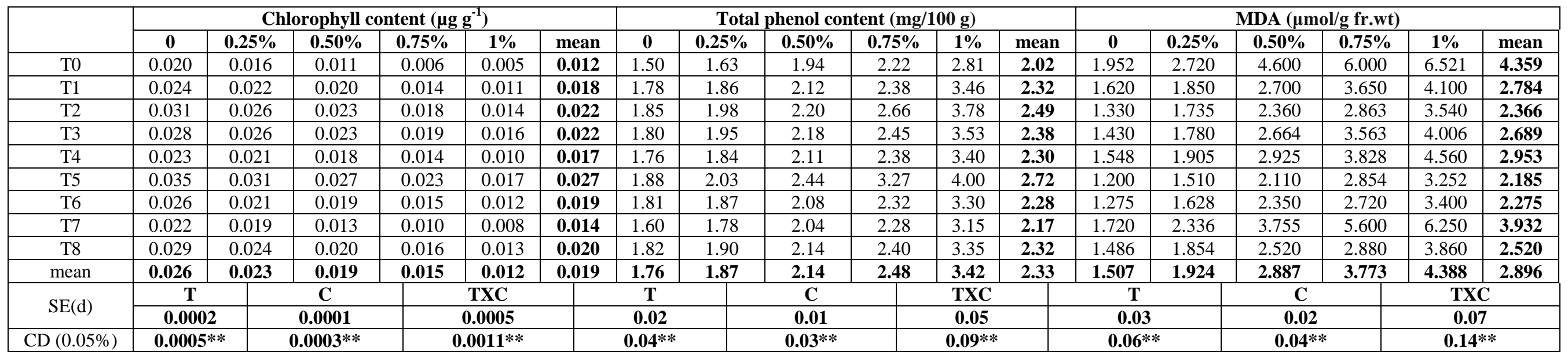


Table.3 Salt tolerance index (STI) amongst treatments at mean value of salt stress condition

\begin{tabular}{|c|c|c|c|c|c|c|c|}
\hline & $\begin{array}{c}\text { Speed of } \\
\text { germination }\end{array}$ & $\begin{array}{c}\text { Germination } \\
(\%)\end{array}$ & $\begin{array}{c}\text { Shoot } \\
\text { Length }(\mathrm{cm})\end{array}$ & $\begin{array}{c}\text { Root } \\
\text { Length }(\mathrm{cm})\end{array}$ & $\begin{array}{l}\text { Phenol content } \\
(\mathrm{mg} / 100 \mathrm{~g})\end{array}$ & $\begin{array}{c}\text { Chlorophyll } \\
\text { content }\left(\mu \mathrm{g} \mathrm{g}^{-1}\right)\end{array}$ & $\begin{array}{l}\text { MDA }(\mu \mathrm{mol} / \mathrm{g} \\
\text { fr.wt) }\end{array}$ \\
\hline T0 & 1.00 & 1.00 & 1.00 & 1.00 & 1.00 & 1.00 & 1.00 \\
\hline $\mathrm{T} 1$ & 1.05 & 1.03 & 1.07 & 1.12 & 1.15 & 1.57 & 0.64 \\
\hline $\mathrm{T} 2$ & 1.26 & 1.09 & 1.20 & 1.26 & 1.23 & 1.93 & 0.54 \\
\hline $\mathrm{T} 3$ & 1.09 & 1.04 & 1.14 & 1.18 & 1.18 & 1.93 & 0.62 \\
\hline $\mathrm{T} 4$ & 1.04 & 1.02 & 1.05 & 1.12 & 1.14 & 1.48 & 0.68 \\
\hline T5 & 1.43 & 1.12 & 1.36 & 1.34 & 1.35 & 2.29 & 0.50 \\
\hline T6 & 1.16 & 1.04 & 1.12 & 1.16 & 1.13 & 1.60 & 0.52 \\
\hline $\mathrm{T7}$ & 1.04 & 1.01 & 1.02 & 1.05 & 1.07 & 1.24 & 0.90 \\
\hline $\mathrm{T} 8$ & 1.12 & 1.07 & 1.19 & 1.22 & 1.15 & 1.76 & 0.58 \\
\hline $\mathrm{SE}(\mathrm{d})$ & 0.02 & 0.02 & 0.02 & 0.02 & 0.026 & 0.038 & 0.015 \\
\hline $\mathrm{CD}(0.05)$ & $0.05 * *$ & $0.04 * *$ & $0.05 * *$ & $0.05 * *$ & $0.053 * *$ & $0.078 * *$ & $0.032 * *$ \\
\hline
\end{tabular}

Fig.1 Effect of seed bio-priming on speed of germination in rice var. PMK 4 - $\mathrm{NaCl}$ salt stress condition

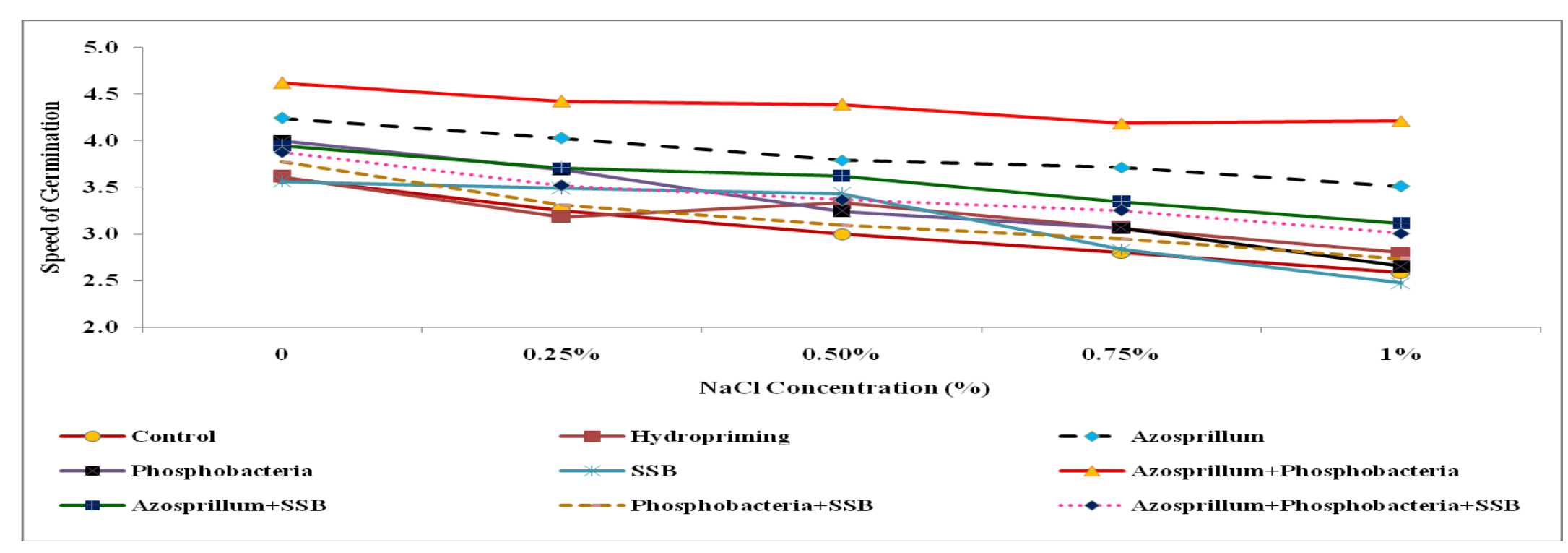


Fig.2 Effect of seed bio-priming on germination (\%) in rice var. PMK 4 - $\mathrm{NaCl}$ salt stress condition

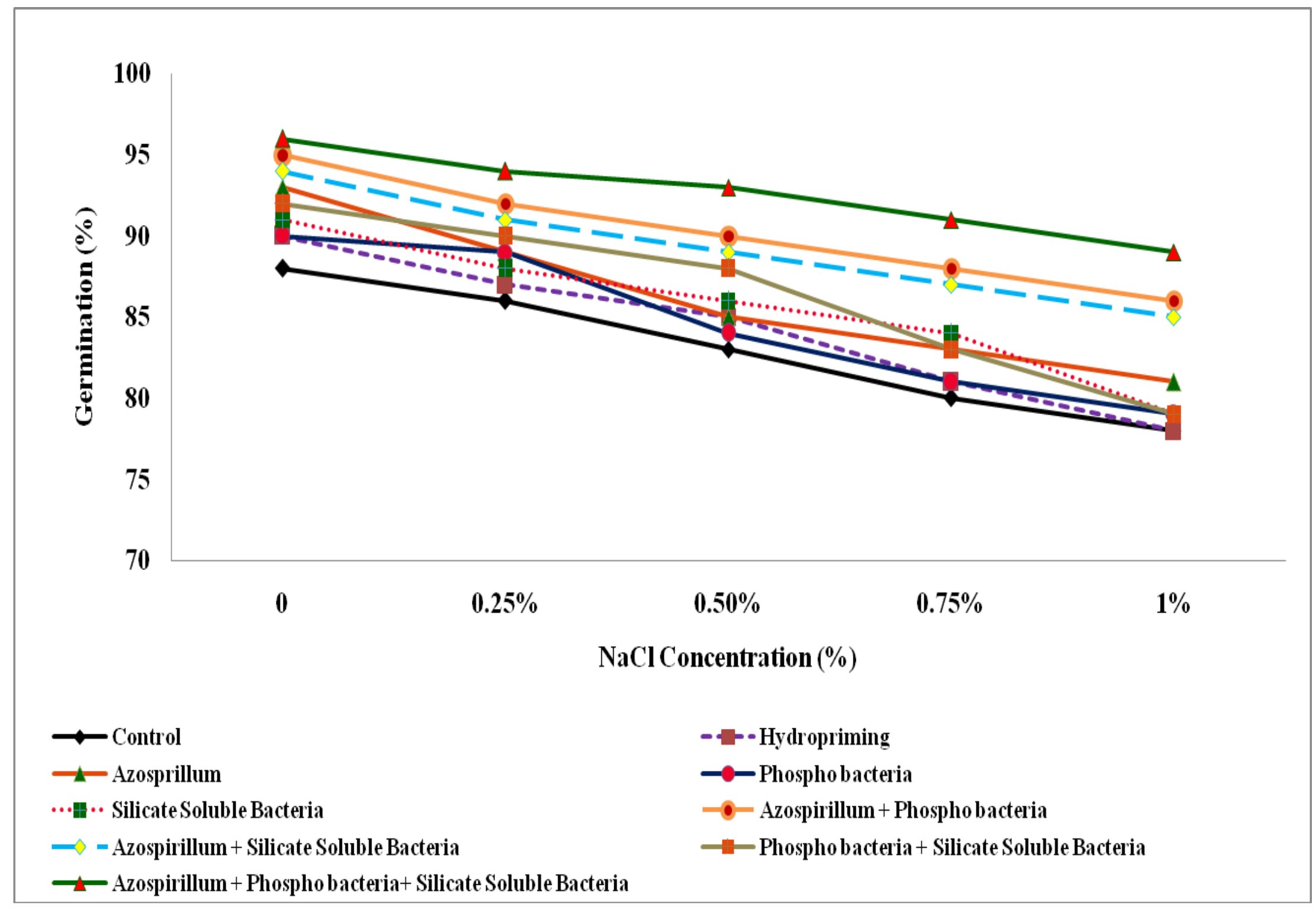


Fig.3 Effect of seed bio-priming on seedling growth of rice var. PMK 4 under i) normal and ii) salt stress conditions

i) Normal condition $(0 \%)$

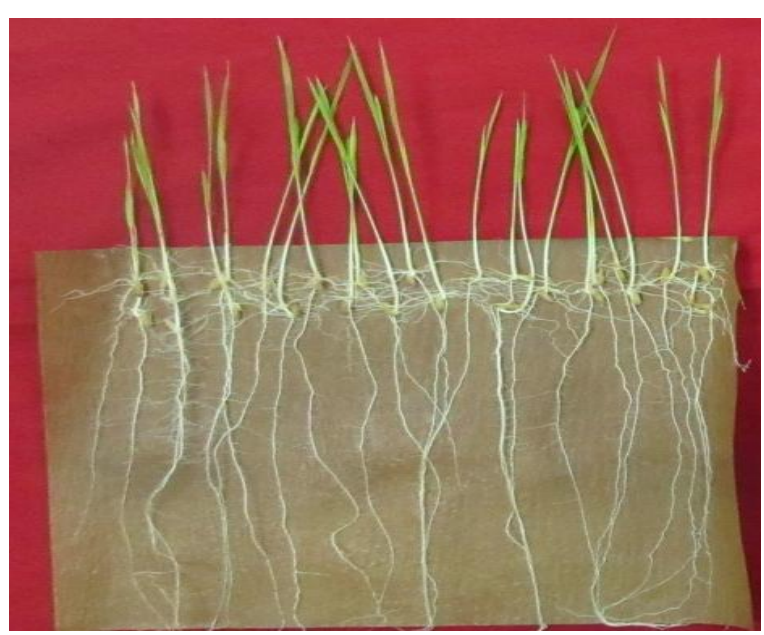

Unprimed Seeds of rice

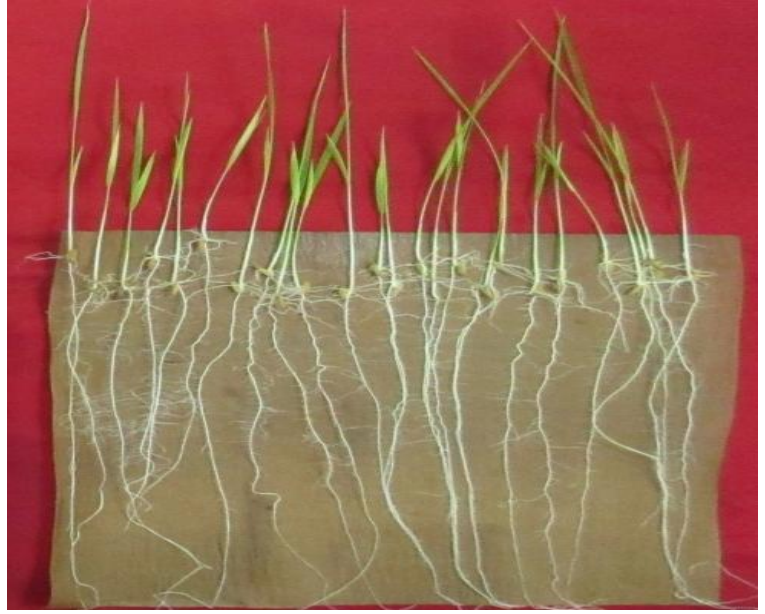

Bio-primed seeds with 20\% (Azospirillum + Phosphobacteria)

ii) Salt stress condition $(1 \% \mathbf{~ N a C l})$

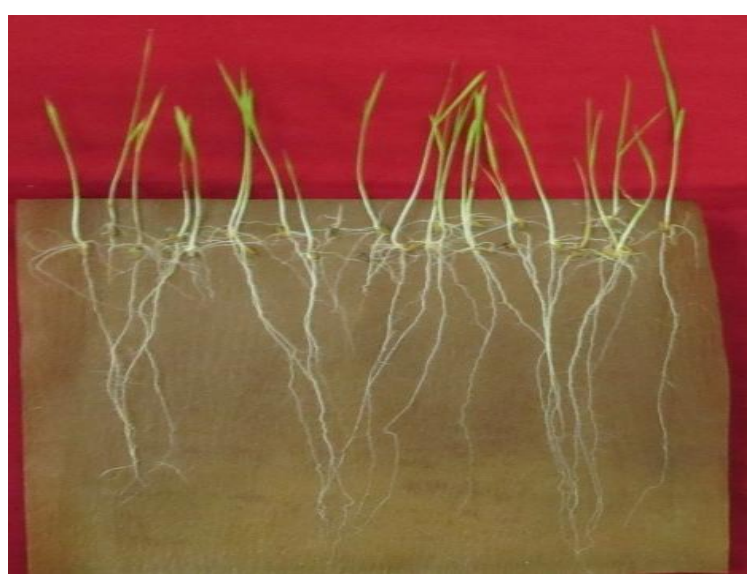

Unprimed Seeds

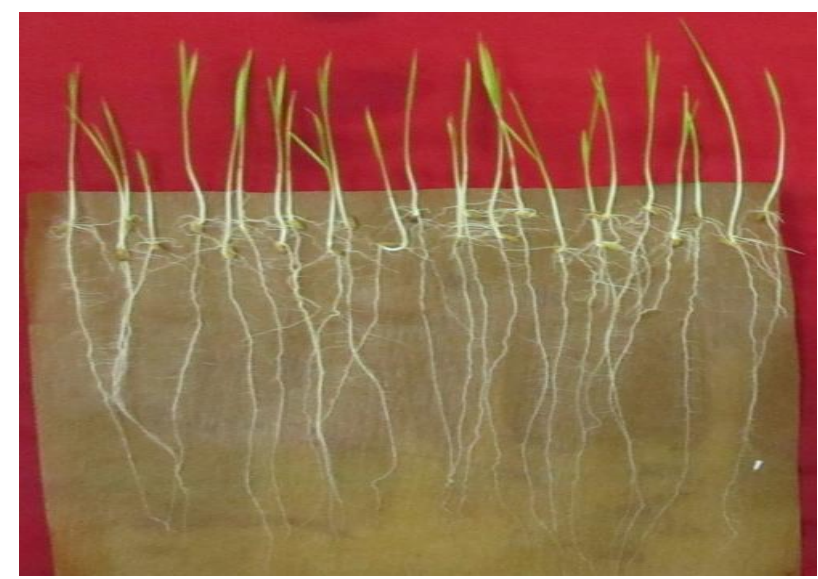

Bio-primed seeds with $20 \%$ (Azospirillum + Phosphobacteria) 
The reduction in vigour of the seedlings due to salinity was reversed by the bio-priming treatments in the present study, expressed as improved vigour index values in all treated seeds and $\mathrm{T}_{5}$ (azospirillum + phosphobacteria) recorded maximum vigour index values both under salt free (3053) and salt stress conditions (2109) than other treatments.

This was expressed as the highest salt stress tolerance index for shoot and root length with seeds bio primed with $\left(\mathrm{T}_{5}\right)$ azospirillum+ phosphobacteria (index 1.36 and 1.34 respectively) compared to control (index 1.00 in each) and other treatments including hydropriming (1.07 and 1.12).

Plants exposed to saline environment generally have reduced chlorophyll content in all treatments. Sodium salt stress decreased total chlorophyll content of plants by increasing the activity of the chlorophyll degrading enzyme; chlorophyllase (Rao and Rao 1981), inducing the destruction of the chloroplast structure and the instability of pigment complexes. In the present study also maximum total chlorophyll content was recorded in $\mathrm{T}_{5}$ (azospirillum + phosphobacteria) under zero level of salinity $(0.035 \mu \mathrm{g} / \mathrm{g})$ compared to control $(0.020 \mu \mathrm{g} / \mathrm{g})$ plants. The total chlorophyll content of leaves averaged over treatments indicated that it decreased from $0.027 \mu \mathrm{g} / \mathrm{g}$ at $0 \%$ to 0.012 $\mu \mathrm{g} / \mathrm{g}$ at $1 \% \mathrm{NaCl}$ indicating the salt stress over the growth of the seedlings. But bio-priming has induced salt resistance to the seedlings and it was expressed as the highest chlorophyll content in $\mathrm{T}_{5}$ (azospirillum + phosphobacteria) treatment $(0.017 \mu \mathrm{g} / \mathrm{g})$ compared to control $(0.005 \mathrm{mg} / \mathrm{g})$ under $1 \%$ level of $\mathrm{NaCl}$. However, the decrease in total chlorophyll content with increased salinity was observed in all the treatments.

Lipid peroxidation is the main index of the increase in active free radicals and MDA is the main by-product of the lipid peroxidation process. Production of MDA, which is an indicative of oxidative stress, increases as salinity stress increases in plant, serves as an index of lipid peroxidation (Meloni et al., 2003). Peroxidation damage of the plasma membrane leads to leakage of contents, rapid desiccation and cell death (Scandalios, 1993). In the present investigation also degree of accumulation of MDA under salt stress condition was higher in untreated plants compared to treated plants. As the salt stress was increased proposnal increase in release of MDA was noticed in all treatments including control (4.359 $\mu \mathrm{mol} / \mathrm{g}$ fr.wt). But lowest MDA content was recorded in seeds bio primed with $\left(\mathrm{T}_{5}\right)$ azospirillum + phosphobacteria $(2.185 \mu \mathrm{mol} / \mathrm{g}$ fr.wt $)$, which might be due to an increase in expression of stress related proteins such as, glutathione Stransferase (GST), glutathione dependent formaldehyde dehydrogenase (FALDH) and peroxidise.

The phenol content was also increased substantially with an increase of salt stress level. Treatments differed significantly both under normal and salt stress conditions.

A significantly higher level of phenol content was observed in $\mathrm{T}_{5}$ as the salt stress increased from $0 \mathrm{dSm}^{-1}$ to $8 \mathrm{dSm}^{-1}$ in comparison to other bio-primed treatments. Highest phenol content under salt stress was observed in $T_{5}$ (azospirillum + phosphobacteria) treatment $(2.72 \mathrm{mg} / 100 \mathrm{~g})$ with salt tolerance indices of 1.35 respectively. Unprimed seeds (control) showed minimum phenol content (2.02 $\mathrm{mg} / 100 \mathrm{~g}$ ) with the lowest salt tolerance index of 1.00 (Table 2).

The PMK (R) 4 seeds bio-primed with azospirillum @ 20\% (treatment number) registered better values for germination $(95 \%)$ and vigour index (2898) parameters observed as next best treatment in all parameters under salt stress conditions (Table 3 ). 
Hence, the present study, revealed that seeds bioprimed with $20 \%$ solution of azospirillum + phosphobacteria withstand salinity stress better compared to all other treatments. expressed in all observed parameters under salinity stress conditions rice seeds may be bioprimed with liquid biofertilizers and their combined treatments to have better performance, which might be due to the fact that azospirillum and phosphobacteria penetrates into the root tissues and initiates a series of morphological, physiological and biochemical changes in the plant.

\section{References}

Abdul-Baki, A.A. and Anderson, J.D. 1973. Vigour determination in soybean seed by multiple criteria. Crop Sci., 13: 630633.

Akita, A. S. and Cabuslay, G. S. 1990. Physiological basis of differential response to salinity in rice cultivars. Plant Soil. 123:227-294.

Almansouri, M., Kinet, J.M. and Lutts, S. 2001. Effect of salt and osmotic stresses on germination in durum wheat (Triticum durum Desf.). Plant Soil. 231: 243-254.

Demir, I. and Van De Venter, H.A. 1999. The effect of priming treatments on the performance of watermelon (Citrullus lanatus Thunb.) Matsum. \& Nakai) seeds under temperature and osmotic stress. Seed Sci. Technol. 27: 871-875.

Epstein, E., Norlyn, J.D., Rush, D.W., Kinsbury, R.W., Kelly, D.B., Gunningbham, G.A. and Wrona, A.F. 1980. Saline culture of crops. A genetic approach. Sci. 210: 399- 404.

Fallahi J, Ebadi MT, Ghorbani R. 2009. The effects of salinity and drought stresses on germination and seedling growth of clary (Salvia sclarea). Environ Str Agric Sci. 1:57-67.

Fallahi J, Rezvani Moghaddam P, Ghorbani
R, Amiri MB, Fallah Pour F. 2011. Effects of seed priming by biofertilizers on the growth characteristics of three wheat cultivars at the germination period under greenhouse condition. In: Proceedings of the 10th Conference of the International Society for Seed Science. Brazilian Association of Seeds Technology, Salvador, Brazil. p.286.

Heath RL, Packer L. 1968. Photoperoxidation in isolated chloroplasts: Kinetics and stoichiometry of fatty acid peroxidation. Arch Biochem Biophys. 125:189-198.

ISTA. 2009. International Rules for Seed Testing. International Seed Testing Association, Switzerland.

Krishna A, Patil C R, Raghavendra S M, Jakati M D. 2008. Effect of biofertilizers on seed germination and seedling quality of medicinal plants. Kar J Agr Sci. 21:588-590.

Lutts S, Almansouri M, Kinet JM. 2004. Salinity and water stress have contrasting effects on the relationship between growth and cell viability during and after stress exposure in durum wheat callus. Plant Sci.167:918.

Maguire, I. D. 1962. Speed of germination aid in selection and evaluation for seedling emergence and vigour. Crop Sci. 2 : 176-177.

Meloni DA, Oliva AA, Martinez ZA, Cambraia J. 2003. Photosynthesis and activity of superoxide dismutase, peroxidase and glutathione reductase in cotton under salt stress. Environ Exp Bot. 49:69-76.

Mer, R. K., Prajith, P. K., Pandya. D. H. and Dandey. A. N. 2000. Growth of young plants of Hourdeum vulgare, Triticum aestivum, Cicer arietium and Brassica juncea. J. Agron. Crop Sci. 185:209217.

Mirshekari B, Baser S. 2010. Effect of seed inoculation with Nitrogen biofertilizer 
on germination and primary growth of rapeseed (Brassica napus), sesame (Sesamum indicum) and sunflower (Helianthus annus L.). J New Agr Sci. 5:91-100.

Panse, V.G. and P.V. Sukhatme. 1985. Statistical methods for Agricultural workers. ICAR Pub., New Delhi.

Rao G.G, Rao G.R. 1981. Pigment composition and chlorophyllase activity in pigeon pea (Cajanus indicus Spreng) and gingelley (Sesamum indicum L.) under $\mathrm{NaCl}$ salinity. Indian J Exp Biol 19:768-770.

Scandalios J.G.1993. Oxygen stress and superoxide dismutase. Plant Physiol 101:7-12.

Song J, Fan H, Zhao Y, Jia Y, Wang B. 2008. Effect of salinity on germination, seedling emergence, seedling growth and ion accumulation of a euhalophyte Suaeda salsa in an intertidal zone and on saline inland. Aquat Bot. 88:331337.
Thimmaiah S.K. 1999. Standard methods of biochemical analysis. Kalyani Publishers, Ludhiana, p 545.

Yagmur M and Kaydan D. 2008. Alleviation of osmotic stress of water and salt in germination and seedling growth of triticale with seed priming treatments. Afr J Biotech. 7:2156-2162.

Yoshida S., Foron D.A. and Cock J.H. 1971. Laboratory manual for physiological studies of rice. International Rice Research Institute, Los Banos, Phillipines. 70.

Zeng L, Poss J.A, Wilson C, Draz A, Gregorio G.B, Grieve C.M 2003. Evaluation of salt tolerance in rice genotypes by physiological characters. Euphytica. 129:281-292.

Zheng C, Jiang D, Liu F, Dai T, Liu W, Jing Q, Cao W. 2009. Exogenous nitric oxide improves seed germination in wheat against mitochondrial oxidative damage induced by high salinity. Environ Exp Bot. 67:222-227.

\section{How to cite this article:}

Nithya, N., R. Geetha, K. Sivasubramaniam, N.O. Gopal and Vanniarajan, C. 2017. Effects of Biopriming on Germination Characteristics of PMK (R) 4 under Salinity Conditions. Int.J.Curr.Microbiol.App.Sci. 6(12): 895-904. doi: https://doi.org/10.20546/ijcmas.2017.612.097 